\title{
Limits of External Reliance for Sustainable Development in Sub-Saharan Africa
}

\author{
Iwara, Iwara Eno, PhD \\ University of Calabar \\ Calabar, Nigeria \\ Dickson, Emmanuel Ekpe \\ University of Calabar \\ Calabar, Nigeria
}

\begin{abstract}
This paper addresses itself to the limits of external reliance for sustainable development in Sub-Saharan African countries. The paper noted that the initial independence expectation that the post independence period would be linked with real economic freedom from oppression, and the people connected with public wealth, has continued to be a mirage. The paper articulates the point that the mainstream advocates' believe in the principle of comparative advantage that has structured state economic behaviour and specialization of the roles of poor countries, rather, promotes western incursions in the critical sectors of development in sub-Saharan Africa. The paper argues that the continued reliance on external ideas, technology, and development policies imposes limits on the quest for sustainable development in sub-Saharan African countries. Finally, the paper delivers the thinking that sub-Saharan African countries should begin to make reasonable budgets for research and development $(R \& D)$ to enhance intellectual probity on development challenges, and for the creation of strategic socio-economic policies for sustainable development in Sub-Saharan African countries.
\end{abstract}

\section{Introduction}

For a period spanning the colonial and post independence era, the Sub- Saharan African countries have developed the tendency, nurtured by external forces, to rely so much on foreign factors for development. Perhaps, the developmental deficiencies manifested in the quest for growth, reinforced the external intervention praxis that promoted such enormous external reliance in Sub-Saharan Africa. The deficiencies include the growing poverty of the people of the region culminating in the lack of power on domestic ideas, the lack of such variables as industrial capital, and technology, as well as the ruling elite's demonstration of very little understanding about how to turn a poor society into a rich one despite the vast endowment of natural assets in most of the Sub-Saharan Africa.

The quest for sustainable development and the initial independence expectation that the post independence period would not only be linked with real economic freedom from oppression, but also that the people would be connected with public wealth has continued to be a mirage. Yet, as it turned out to be, over 50 years of political independence, except perhaps Botswana, other Sub-Saharan African countries are still facing the complexities and uncertainties of external reliance for sustainable development (Todd, 2007:1)

These complexities and uncertainties have somewhat continued to promote a behavioural pattern of state life in which state mentalities conceptualize development as purely political, and expected to be driven by external forces or global institutions. In other words, the Sub-Saharan African governments have come to see external reliance for development as a deliberate strategy of development (Adedeji, 1999:16-37). The external reliance syndrome was accentuated and articulated in the post-independence development plans. For instance, Nigeria's first and second National Development Plans (1962-1974) were designed with about 50\% funding from external sources (Iwara, 2004:107).

It is no longer news that the plans failed and the reasons given for their failure hinged the blame particularly on external reliance especially the reliance on the Harold and Domino Model of development which the plans adopted, and the failure of counterpart financing of the projects as at when due (Olashore, 1991:132) Generally, the externalist internalist debate prevalent in the extent literature provides us with an illuminating picture of understanding the external reliance bundle in Sub-Saharan Africa.

Externalist (mainstream) arguments usually encourage external reliance on foreign ideas, formidable external theories of development, and technology which of course are instruments of the so called modernization and free market economy advocacy (Nwoke, 2013:7). For him, mainstream thought pattern usually enables the West to make incursions in the critical sectors of development in Sub-Saharan Africa. 
This mainstream or conservative neoclassical economic thought is represented in studies published by the World Bank and the International Monetary Fund (IMF). The neoclassical economic proposition specify the roles of poor countries in the international economic system, limiting such countries to the supply of raw materials obtained from the development of agriculture driven towards export.

The proposition of the mainstream or conservative thought towards the promotion of policies in Sub-Saharan Africa is targeted towards the abandonment of the protection of the domestic industry by African governments. According to Samir (1988: xii), this proposition is frequently engineered by the mainstream advocates believe in the principle of comparative advantage. This class of thinkers goes to any length to power their strategies, in their bid to create a global economy in their own image. For instance, the proposition of the Group of 77 for a New International Economic Order (NIEO) to seek favorable terms of trade for primary commodities and revaluation of trade rules, and redistribution of global wealth based on revisiting the theory of dependency, among others, was frustrated at the level of the United Nations Conference on Trade and Development (UNCTAD) championed by the metropolitan countries, who were in favour of a radical replacement of the proposition by debt forgiveness and debt reduction (John and Jerry, 2006: 84). Thus, the proposition of the Group of 77 for which SSA countries were a part, could not survive, as liberalism fostered theory of comparative advantage continues to take its toll in the economies of SSA countries (Moore and Pubantz, 2006: 156).

In the face of all these psycho-economic maneuvers of the neoclassical economic theorists of the metropole, it is surprising that such propositions and actions that continue to limit the development ability of the Sub-Saharan Africa countries are still being allowed to persist without relieving strategies. It is a well known fact therefore, given such maneuvers, the implication is that the SSA countries are limited in promoting development variables like technology, industrial capital and intellectual depth in critical sectors that would have occurred due to continuous processing of raw materials into finished or manufactured goods. The limitations arising from the above and for which SSA countries are reliant on external donors, aggravated external control and continuous deepening of external reliance in Sub-Saharan Africa. Nwoke (2013:06) captured this situation in the following words:

External control bolstered up tendencies towards dependence, and deepened the crisis of development...The one prescription that the foreign experts are usually unwilling to try is that of empowerment and self reliance.

The external control matrix has two implications; the first is that the diagnosis of problems and pace of sub-Sahara African development remain externally determined. Second is that, the intellectual component or philosophy of development which dictate the typology and quality of development on which is inherent the competitive power of Sub-Saharan region in the global economic interchange will continue to be manipulated by foreigners.

On the other hand, internalist arguments are centered on the inability of the ruling elite in Sub-Saharan Africa to pilot the affairs of their people in a progressive manner. For such arguments, rather than blame external forces, the internal forces should be held responsible. The main thrust of the internalist hold that Africanstates generally are constituted largely by comprador elements, that is, indigenous businessmen and women, politicians and other civil and military functionaries, who help to facilitate and sustain the imperialist ambitions and domination of their respective countries. Some of these internalist scholars blame the woes of Sub-Saharan Africa on corruption and lack of commitment to development programmes (Ekekwe, 1968, Olopoenia, 1998 and Iwara, 2009).

What is clear from the externalist and the internalist debate over the reliance of Sub-Saharan African is that, the countries in the region have developed a mentality of continuous external reliance that is vulnerable to external control. What is also clear is that external interventions coupled with the lack of absorptive capacity for external assistance on the part of the ruling elite in Sub-Saharan African countries, have created limits which adversely affect sustainable development in Sub-Saharan Africa. To this end, the paper proceeds with the claim that external reliance for assistance loses its benevolence what so ever, once the recipient government lacks absorptive capacity. It is along this line of thought that the paper examines the three moments which characterize external reliance contexts in Sub Saharan Africa as the foregoing 'introduction' clearly indicates. These are; external ideas, technology, and development policies. The examination of these contexts would enable the work unravel the real limits of sustainable development in Sub Saharan Africa. The paper is organized in four sections. Section one is the foregoing introduction. The second section takes on the conceptual perspectives, where the major concepts used in this paper are engaged in a prologue. Section three is the body of the paper. It interrogates the limits imposed by the variables of external reliance like external ideas, technology, and external development policies, especially their trajectories and shocks which punctuate sustainable development in Sub-Saharan Africa. Finally, section four concludes the discourse. 


\section{Conceptual Perspectives}

Some of the concepts used in this work require clarification and prologue in other to explain their meaning and how they are applied in the work. The concepts are: limits/external reliance; sustainable development; and Sub-Saharan Africa.

Limits/Eternal Reliance: This is a composite concept comprising of 'limits' and 'external reliance'. Limits are generally defined as impediments to the growth or development of a phenomenon. The mathematics literature of definitions gave what this paper adopts as limits. For the mathematics literature, limits connote two related meanings. In the first, limits are points or levels where progress may not pass or extend. In the second, limitsare restrictions or sizes or amounts permissible (https://www.themathpage.com).

External reliance involves dependency on foreign assistance or help. Todd (2007:3) argues that the uncertainties and complexities of development faced by Sub-Saharan African Countries and of course the Third World, created the vulnerability for external reliance. He then concluded that foreign help was not automatic for development to occur because of limits such as inequitable international order and psycho-economic maneuvers that are usually attached to foreign assistance. For him also is the dreaded issue of corruption of both internal and external actors, as well as bad governance, which constitute as expedients that pose as intervening variables which have to be overcome before development can take place. In sum therefore, the concept of limits of external reliance is herewith seen as the permissive levels external reliance can go given the lack of absorptive capacity in Sub-Saharan Africa to facilitate development. The paper deploys this character of external reliance to create understanding of the quagmire in which SSA Countries are trapped.

Sustainable Development: This is a system of Development that has the present generation of people and the future generations of people in its calculus. It implies meeting the needs of the present generation of people without compromising the needs of future generations of people. The hallmark of sustainable development is citizen participation in development affairs. It advocates that people play their roles no matter how infinitesimal, and drawing strength or empowerment from the wealth of the state (www.sd.commision.org.uk). The key variable of sustainable development involves environment, economic and social.Sustainable development advocates that environmental resources are key variables for social empowerment and as God given variables or natural assets; they have to be used with caution so that future generations would also have access to them. It is because the environment harbours the assets of survival and offers wide ranging opportunity of people's participation in development that some political economists promote the idea of sustainable development. It is also within this context that political economists tell us that the natural resources that abound the environment to a large extend determine the production and distribution structure of the State economy (Iwara, 2009:35). The issue therefore is the extent to which Sub-Saharan African Countries have been able to harness these natural assets with external reliance.

Sub-Saharan Africa: This is the region of Africa, lying South of Sahara. To the United Nations, the Sub-Saharan Africa geographically consists of all African countries lying south of Saharan. This means countries fully or partially located south of Saharan (UNDP, April 2010 Archives). For the UNDP, the SSA region is made up of 48 countries of Africa with the exception of North African countries such as Morrow, Egypt, Libya and Tunisia. Some of the major languages spoken in Sub-Saharan Africa include Swahill, Lingala, Zulu, Yoruba, Hausa and Igbo (Francistapon.com). Some countries of North Africa that are not part of the Arab League are also part of the countries of Sub Saharan. The countries include, Djibouti, Comoros and Arab speaking Mauritania that are geographically in Sub-Saharan Africa (https:www.africa.undp.org).

Generally, Sub-Saharan African countries are the poorest in the world, and they suffer from the legacies of colonialism, on the basis of which they can be studied together. In addition, the governments of Sub-Saharan African States face challenges of external policy implementation in view of differences of the environmental peculiarities of the external policy promoters in comparison with that of the Sub-Saharan Africa.These environmental differences have usually been attributed to why it is difficult for Sub-Saharan governments to mitigate underdevelopment using externally made policies (https://www.coc.gov.).

\section{Limits of External Reliance in Sub-Saharan Africa}

Having discussed the perspectives of the major concepts, the paper returns to the problematique of this paper that accentuates the real limits of external reliance in Sub-Saharan Africa. There are several influences occasioned by external assistance which affect the quest for sustainable development in Sub-Saharan Africa countries. These influences or donor conditionalities in conjunction with the lack of absorptive capacity in SSA Countries impede sustainable development in Sub-Saharan African countries essentially because the external matrix of development usually neglects the needs of the masses. 
Some experts attribute the development crisis to the differences in the policy environment peculiar to the external policy makers and the Sub-Saharan Countries where such policies or ideas were usually dumped for implementation.

In the attempt to discuss the crisis, it became plausible to examine the contexts where external reliance is domiciled, particularly those factors that characterize the external reliance syndrome. To this end, the paper tries to consider the balance of argument in the externalist-internalist debate over the woeful conditions of sustainable development in SubSaharan Africa.

The basic assumption of this segment of the paper is that, external reliance deepens the control of the Sub-Saharan African countries' critical sectors of development. In view of this assumption, the paper examines critical ideational factors which shape sustainable development, and which are not permitting SSA countries to deliver development to the masses such as: (a) Reliance on External Ideas (b) Technology and (c) Development Policies.

(a) Reliance on External Ideas: Generally, an idea is a thought or view or suggestion that usually attempts to influence a possible course of action.In other words, an ideal is a plan or design or a scheme or a proposition (Nasidi, 2001:14). For Nasidi, the power of an idea is in its ability to capture, harness and sustain it over time. For the American Management Association (https://www.amanet.org) the power of an idea is the power to achieve by thinking. For Montoya (https://www.qudra.com) ideas usually develop into concepts and they are worthless unless they culminate into plans. Experience however has shown that, external ideas emitted by foreign forces for development in poor countries of the world by powerful countries and western institutions, are usually found to be in collusion course with the peculiarities of poor recipient countries (Ogunsanwo, 2015:85).

In the area of politics, coherent ideas are usually known as ideologies which promote particular development and world view, both imaginary and ontological. Political ideas cover wide range of human interests in political, economic, cultural and social contexts that relate to real conditions of existence. The fore going perspectives of ideas tell us about three important variables: thinking process, plan, and power to capture and achieve.

Flowing from the above perspectives are two questions: (i) Do Sub-Saharan African (SSA) countries have the thinking processes, plans and the power to capture and achieve development in their ideas?(2)What are the real limits of the SSA countries' reliance on the ideas of foreign donors?The solutions to thesequestions are littered in the extant literature.

For instance on the first question, it is a well known fact that development ideas abound in SSA countries, but the ruling elite appear to tune-off from the domestic ideas because of the mentality that foreign ideas are superior. These ideas can be seen in the epistemological resources of scholars of the region. These locally developed ideas can be found in libraries, research institutions, and other centers that house emanating from conferences, workshops and other institutional arrangements. However, there are at least two critical challenges which deny such ideas the compelling force for their utilization by the ruling elite. The first is that the scholars or intelligentsia are not organized as a national corps of experts for purposes of achieving plans, clear processes and power to achieve development from the ideas by the government, as noticeable in metropolitan countries such as US and even South Korea recently (Iwara, 2015:09-17) The challenge is that, the governments of SSA countries behave like brainwashed people that are not disposed to accepting auto-centric ideas, and not willing to make budgets for empirical and scientific studies for development think tank from where they can derive knowledge or market based development (Nwolise, 2006: 31-63).

On the second question, what is clear is that, the jettisoning of auto-centric or home-grown ideas, either by omission or commission, creates vulnerability for the SSA countries to rely on external ideas or make the adoption of external ideas inevitable in the quest for development. Here again, there are two limitations for SSA countries: the first is that the identification and probity of SSA problems are left to foreign forces who are ignorant of the domestic needs of the masses; the second is that, the ideational factors that shape development are in foreign hands. In view of the exclusion of the masses in that regard, sustainable development becomes elusive. For instance, the liberal idea of market economic system in poor countries is a pointer to this fact. The elusiveness of sustainable development is a major limit of reliance on external ideas.

(b) Technology: Technology is another variable of external reliance in SSA that may not be too different from ideas, because it is coherent ideas that gives birth to skills and techniques normally regarded as technology. Technology is essentially a potent instrument of development. It involves techniques of knowledge and skills for carrying out processes of work. Every society needs technology to be able to engage in meaningful sustainable development. In view of it insufficiency in Sub-Saharan Africa, the countries in the region rely on technology owners of the western world. The quest for technology attainment has so far taken a bipartite approach in SSA: namely, technology transfer and partnership. None of these approaches has so far yielded positive outcome (Agbu, 2013:230-263). Nwolise (2006: 31-63) noted that transfer of technology is unthinkable because it takes complex processes of negotiation. 
For instance, according to him, technology owners retain copy right as technology does not occur in a vacuum, but a property that emanates from research and innovation from countries that invest in research and development (R\&D).

The Sub-Saharan African countries are limited by the imposition of the technology holders on grounds of the limits foreign technology imposes on industrialization. For instance, external technology limits the production quality and quantum of Sub-Saharan African countries. It creates bottle-necks in spare parts and associated services. This account for why technology recipient States cannot change their world significantly, and a major reason why recipient states cannot compete favourably in the international economic interchange (Iwara, 2015: 4340-4345). For instance, when Nigeria acquired technology from technical partners in the 1980s for paper production that was aimed at making the country self sufficient in the production of News print, Bond, and Kraft papers, and the technical partners withdrew their interests, all the paper mills sited at Jebba, Iwopin, and Oku-Iboku, became moribund. This occurred largely because of the withdrawal of the technology holders that they relied on, though coupled with the lack of commitment of the Nigerian State. So industries that rise and fall do so partly because of limits imposed by external technology reliance.

(c) Development Policies: These are conscious decisions which usually aim at reducing poverty, and to implement fundamental principles to promote sustainable development. Development Policies encompass policy dialogue with individuals, groups of representatives of institutions and countries to arrive at decisions that can be useful for development, either at municipal or international level (Addison, 2004:3). There are over one billion of people living in abject poverty world-wide (Burnell and Randall, 2004:18), majority of which live in Sub-Saharan Africa. The question, here is, to what extent have external development policies promoted in Sub-Saharan Africa, reduced poverty in the region? Perhaps, this question can be answered by examining two development policy frame works like the Millennium Development Goals (MDGs) and the structural Adjustment Programmed (SAP).

Millennium Development Goals: The United Nations General Assembly (UNGA) millennium summit in September 2000 attended by 149 Heads of states and Governments adopted what they considered the Millennium Development Goals (MDGS) which they believed were capable of reducing poverty world-wide. The MDGS have eight focal targets for improving the lives of people in such areas as:

i. Eradication of extreme poverty and hunger

ii. Achieve Universal Primary Education

iii. Gender equality and women empowerment

iv. Reduction of child mortality

v. Improve maternal health

vi. Combat HIV/AIDS, malaria, and other diseases

vii. Environmental sustainability and

viii. Develop global partnership for development.

All world leaders pledged commitment to ensure the achievement of the goal by 2015 (MDG, 2015 Report).By 2005 UN progress report, the Sub-Saharan Countries were reported to be dramatically facing downward trend, showing poor situations in environmental degradation, resurgence of preventable diseases and astronomical poverty and hunger (https://www.google.com).

Apart from the progress made by Burkina Faso and Niger, other Sub-Saharan Africanstates were said to have failed to achieve at least two -thirds of the MDGS target and so classified as "off target". Some of the reasons given for their failure include the lack of appropriate yard stick to monitor progress, and also the fact that economic growth in SubSaharan Africa was poor when the campaign for implementation started by 2000 . The failure to a large extent exposes the lack of commitment and poor governance on the part of the concerned SSA countries. Nigeria for instance performed woefully in meeting the 2015 target, ranking among the bottom ten countries in the interim evaluation in 2010 (Ajakaiye and Jerome, 2013:3). Again, the failure to make significant leap under the MDGS imply clearly that there was failure in producing interlocking economic and political incentives for citizens in Sub-Saharan Africa. It also indicates that political and economic institutions do not have the people as their primacy (MDGS Report, 2015:12). For Ajakaiye and Jerome, (2013:5) it was abundantly clear that:

Aid donors did not fund large scale infrastructure projects which would

have profoundly facilitated the empowerment of the people through employment, to raise per capita income.

For them therefore, poor infrastructure and poor policy responses as well as external shocks were the major undoing of the poor performance of Sub-Saharan Africa under the MGDS. 
The foregoing discussion on the MDGs, indicate such limits as infrastructural deficit, policy responses and external shocks standing against the performance of Sub-Saharan African countries. Essentially, these deficiencies tell us about the lack of absorptive capacity for foreign assistance and reliance.

Structural Adjustment Programme (SAP): This programme was somehow imposed in the mid 1980s, when the growth rate of Sub-Saharan Africa countries lost momentum. The first 15 years of independence witnessed improved economic activities but that initial sign of growth ran into economic hitch following severe balance of payment deficits and the growing import needs of domestic industries.

The structural adjustment programmed therefore aimed at reducing the role of the state in the development process and to give market forces a greater role (Todd, 2007:106).

However, despite vigorous implementation of SAP in many Sub-Saharan African Countries, including countries that did not actually obtain the loans from the donors, the impacts and influences of the conditionalities, had negative telling effect on the citizenries. Some of the conditionalities of the donor institutions under SAP include: the decision that any support for Africa would require liberalization, states would have to curb mismanagement; get out of loss-making ventures; stop regulating the economy, and sell off the state owned enterprises that would be better managed by the private sector. SAP remained for its advocates such as Internal Monetary Fund (IMF) and World Bank, the beginning of a policy-based lending which continues till today (Obadan and Edo, 2010:14-36).

In practice, it was observed that SAP conditionality was near absolute failure. In other words, the limits of Sub-Saharan Africa Countries under SAP include, the inability to apply the IMF/World Bank structural reform measures taking cognizance of the import-dependent nature of the industrial sector; market imperfections and contradictory fiscal and money policies among others (Obadan and Edo, 2010:14-36). These limits constrained the Sub-Saharan Africa Countries from realizing or benefiting from the structural adjustment programmed.

\section{Conclusion}

The concluding theme here is that apart from the growing poverty conditions of Sub-Saharan African Countries, the ruling elite in the region has demonstrated very infinitesimal understanding about how to transform poor societies into rich ones. The paper found that tendencies emitted by government of the Sub-Saharan Countries, as nurtured by external forces, promoted external reliance syndrome. The paper contends that both externalist and internalist arguments provide us with an illuminating picture of understanding the external reliance bundle in Sub-Saharan Africa.

Critical in understanding the quagmire in Sub-Saharan African Countries was the psycho-economic maneuvers in the ideas such as the comparative advantage and conditionalities promoted the metropolitan countries. The psychoeconomic maneuver was the major reason why the SSA Countries were slow in the development of technology, industrial capital and intellectual depth in critical sectors that would have occurred due to continuous processing of raw materials into manufactured goods. It was also a major impediment that aggravated the continuous reliance on external ideas, technology, foreign industrial capital and external development policies.

The implication of the foregoing quagmire requires that SSA Countries address the following challenges:

1. It is important in view of the identified limits imposed by the reliance on external ideas to encourage the critical production of development ideas by nationally configured National Intellectual Corps in Sub-Saharan African countries. The region of Sub-Saharan should not continue to remain within the narrative of external reliance for basic development ideas. The prevailing paradigm where scholars or researcher produce ideas that are littered in libraries and research institutions without receiving the attention of government or those saddled with the responsibility of State development is not desirable. It is the responsibility a national corps of intellectuals or experts, acting the 'high ground' of the State to produce ideas loaded with processes and plans, with the power to achieve development in critical sectors. The experiences of the Chicago School, an intellectual Corps of United States, which advocated the idea of the formation of the United Nations Organization to prevent future world wars, and the Samuel Undong Intellectual society of South Korea, which helped in the eradication of illiteracy in South Korea, are clear examples.

2. On the issue of reliance on foreign technology, the paper clearly highlighted the grave implications such as, the determination of quality and quantum of production levels by foreign forces, which is a risk for independent countries in a competitive world. In order to escape from such quagmire, the SSA countries would need to build strategic partnerships for technology acquisition, and also reinforce the African traditional techniques and skills that were stunted by the colonial forces. The limitations imposed by donor-technology should be avoided so that SSA countries can compete favourably and develop latitude in international economic interchange among others.

3. Development Policies should begin to take the SSA environmental peculiarities into account, and essentially develop ideational factors that would shape sustainable development order in Sub-Saharan Africa. 
Finally, as the $21^{\text {st }}$ Century rolls by, Sub-Saharan African Countries should begin to seriously make reasonable budgets for Research and development (R\&D) for the creation of strategic socio-economic policy for sustainable development based on each country's environmental peculiarity.

\section{References}

Addison, T. (2004) Development Policy, An Introduction, Discussion paper 2004/9, United Nations University, New York.

Adedeji, A. (1999) TheRole of Foreign Aid in Development. Issues in contemporary political Economy in Nigeria, Sally and Association, Ilorin.

Agbu, O. (2013) Technology in International Relations, Implications for Nigeria's Foreign Policy, in Nigerian Journal of International Studies Vol. 38, No 1 \&2 PP230-263.

Ajakaiye, O. and Jerome, A. (2013) Economic Development the Experience of Sub-Sahara Africa, Review of Africa's Development. (https://www.africanprogresspanel.org.)

Burnell, P and Randell, V. (2004) Politics in World, Oxford University Press, Oxford

Ekekwe, E. (1986) Class and State in Nigeria, Longman Nigeria ltd, Lagos.

Iwara, I.E. (2015) National Intellectual Corps and the Political System Development in Nigeria, in International Journal Advances in Social Sciences and Humanities, Vol. 3, No. 8, pp 09-17

Iwara, I.E. (2015) International Politics of Technology and its implications for Development in Africa, in International Journal of Development Research, Vol.5 issues 5 pp 4340-4345

Iwara, I.E (2009) Themes in Modern political Economy, College Press, Ibadan.

Iwara, I.E. (2004) foreign Aid and National Sovereignty in Nigeria, PHD Thesis, University of Ibadan.

Moore, J. A. and Pubantz J. (2006) The New United Nations International Organization in the $21^{\text {st }}$ century, Pearson Prentice Hall, New Jersey 07458.

Nasidi, Y. (2001) Beyond the Experience of limits: power in African literature, caltop publications Ibadan.

Nwoke, C. N (2013) Illusion of Euro/American Partnership in Development with Africa, in African Journal of International Affairs and Development (AJIAD)Vol. 17 (1\&2).

Nwoke, C.N (2013) Rich land, poor people: A politica Economy of under development in Nigeria, $3^{\text {rd }}$ Inaugural lecture, lead City University, Ibadan.

Nwolise, O.B.C (2006) Socio-economic impacts of Market Driven Research and development in National security and growth, in the Nigerian Army Quarterly Journal, Vol. 2, No 2 pp31-63.

Obadan, M. and Edo, S. (2010) Over all Economic Direction, Strategy and performance of the Nigerian Economy, in 50 years of the Nigerian project: Prospects and challenges (ed) Bello-Iman, College Press, Ibadan,

Ogunsanwo, A. (2015) Selected Essays on Politics and International Relations, Concept Publications Limited, Lagos

Olashore, O. (1991) Challenges of Nigerian Economic Reform, Fountain Publications, Ibadan.

Olopoenia, A. (1998) A political Economy of corruption and under development, $10^{\text {th }}$ faculty of social science lecture series, University of Ibadan

Samir, Amin (1988) Mining in Africa Today "Preface" Tokyo: United Nations University

Todd, J. M (2007) African Development: Making sense of the issues, New York University.

Walter R. (1972) How Europe under developed Africa, BogleL'ouverture publications, united kingdom

Montoya Jason Scott "The Power of Ideas (https://www.guora.com) 